\title{
Pemanfaatan Tanah Wakaf Sebagai Prasarana Dakwah di Kecamatan Tebat Karai
}

\author{
Budi Birahmat, MIS \\ IAIN Curup \\ al fajry08@yahoo.com \\ Nesy Farlina \\ IAIN Curup \\ nesifarlina@gmail.com
}

\begin{abstract}
Waqaf is a practice that has a very high value in Allah SWT, because waqaf is a practice whose benefits can be felt continuously even though the one who donated it has passed away, the use of waqf land in general is for the benefit of the Islamic community in general but there are also those who are donated specifically for the benefit of Da'wah, the interest in land waqf in the Tebat Karai sub-district, Kepabiang Regency is very good because almost every village has waqf land, the use of the waqf land has been criticized by Tebat Karai Kepabiang including the building of mosques, mushalla, public cemeteries and schools, although there is no allocation of waqaf land which is specifically used for movement. Da'wah institutions in particular but in general the allocation of the waqaf land in the Karai Kepabiang sub-district has been earmarked for the interests of syi' ar Islam.
\end{abstract}

Keyword: Da'wah, Da'wah Infrastructure, Tanah wakaf

\begin{abstract}
Abstrak
Wakaf merupakan amalan yang sangat tinggi nilainya disi Allah SWT, karena wakaf merupakan amalan yang manfaatnya dapat dirasakan secara terus menerus meskipun yang mewakafkannya sudah meninggal dunia, peruntukan tanah wakaf pada umumnya adalah untuk kepentingan uamt Islam secara umum tetapi juga ada yang diwakafkan secara khsus untuk kepentingan dakwah, minat wakaf tanah dikecamatan Tebat Karai Kabupaten Kepahiang sangat bagus karena hampir disetiap desa mempunyai tanah wakaf, peruntukan tanah wakaf dikecamtan Tebat Karai Kepahiang meliputi bangunan Masjid, mushalla, Tempat Pemakaman Umum dan Sekolah, meskipun belum ada peruntukan tanah wakaf yang digunakan khusu untuk pergerakan Lembaga dakwah secara khsus tetapi secara umum peruntukan tanah
\end{abstract}

Jurnal Dakwah dan Komunikasi

IAIN Curup-Bengkulu | E-ISSN : 2548-3366, P-ISSN:2548-3293 
wakaf di kecamatan tebat karai kepahiang sudah diperuntukkan untuk kepentingan syi'ar agama Islam.

Kata Kunci: Dakwah, Prasarana Dakwah, Tanah wakaf

\section{Pendahuluan}

Agama Islam mempunyai landasan syari'ah yang yang mencakup seluruh aspek kehidupan, dasar ajaran Islam itu meliputi akidah, syariah dan aklak yang satu dengan yang lainnya tidak dapat dipisahkan, konsep dasar (aturan-aturan) agama Islam tersebut di syari'atkan epada sekalian alam melalui Rasulullah SAW untuk menjadi dasar dalam kehidupan manusia baik dunia atau akhirat, ${ }^{1}$ begitu juga pemahaman masyarakat terhadap syari'ah, akidah dan akhlak tidak dapat dipisahkan dengan penyiaran dakwah baik secara langsung ataupun tidak langsung.

Penyebaran dakwa ditengah-tengah masyarakat membutuhkan pendakwah yang dapat berkomunikasi dengan ummat secara bijak sehingga umat bisa memahami dakwa dengan cara yang gampang, karena islam adalah agama dakwah maju mundurnya umat Islam sangat tergantung kepada kegiatan dakwah yang dilakukknya ${ }^{2}$, bahkan al-qur'an menyebut kegiatan dakwah dengan istilah absanu qoula (surat Fushilat :33), akan tetapi persolan dakwa tidak hanya tentang ketersediaan para Da'I atau pendahkwah saja tetapi, juga prasarana dakwah.

Dalam mengembangkan dakwah kepada umat tidak bisa dipisahkan dari sarana dan prasaran untuk menunjang dakwa tersebut baik secara formal seperti sekolah datusn madrasah atau non formal seperti Mesjid, Musollah dan tempat lainnya yang digunakan sebagai tempat menyebarkan ajaran syari'at.

Penyebaran dakwah kepada umat bukalah tanpa ada halangan dan hambatan, tidak jarang kita temukan suatu misi dakwah terkendala karena sarana yang minim sebagai tempat pengembangan dakwah baik yang bersifat formal atau non formal, seperti banyaknya sekolah dan madrasah yang yang terkendala oleh lahan untuk mengembangkan sara pendidikan atau tidak sedikit persoalan hukum yang belum selesai terhadap lahan yang menjadi sarana atau tempat pusat dakwah.

Kebutuhan terhadap lokasi dakwa sebenarnya agama islam telah memberikan sebuah motivasi kepada umatnya berupa penghargaan pahala yang tidak putusa-putus bagai orang yang bersedia memberikan hartanya untuk kepentingan dakwah sebagaiman hadis Rasulullah SAW :

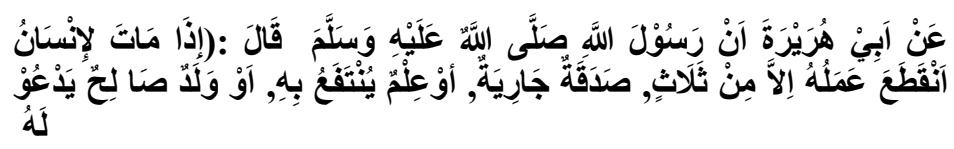

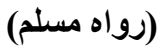

${ }^{1}$ Nur Ahmad: Perayaan Gerbeg Besar Demak Sebagai Sarana Religi dalam Komunikasi Dakwah (Jurnal At Tabsyir STAIN Kudus, 2015), 4

${ }^{2}$ Didin Hafiduddin, Dakwah Aktua l(Jakarta Geme Insani Press.cet. 3 1998), 76 
Dari Abu Hurarirah Ra., bahwa Rasulullah Saw. bersabda : "Ketika manusia meninggal duni maka amalnya putus darinya kecuali karena tiga hal: shadaqah jariyah, ilmu yang bermanfaat dan anak sholeh yang mendookan orang tuanya". (H.R. Muslim) ${ }^{3}$

Dari hadis Rasulullah di atas ada motivasi bagi umat Islam aga mereka memberikan sedekah dalam bentuk seedekah jariah yang zat nya kekal yagn pemenfaatannya dapat secara terus menerus untuk kepentingan tidak terkecuali untuk kepentingan dakwah. Hal ini telah memotivasi banyak dari uamt Ilsam mewakafkan tanah mereka untuk kepntingan syari'at atau ada juga yang memfokuskan untuk kepentingan dakwah seperti sekolah dan masjid.

Sarana berupa lokasi dakwah khusunya tanah bukanlah tanpa kendala dan hambatan, terkadang tanah wakaf yang pada mulanya diberikan oleh pewakaf secara iklas yang tidak dicatatkan secara aturan hukum tidak sedikit menuai kontropersi dibelakang hari atau tidak sedikit tanah wakaf untuk Masjid berobah menjadi pasar, masalah lain juga ditemukan adanya tanah wakaf untuk dakwa tetapi tidak dikelola secara profesional sehingga terbengkalai.

Pada perkemabngannya, wakaf kini telah mengakar dalam kehidupan masyarakat Islam, dan menjadi penunjang utama dalam kehidupan masyarakt tidak terkeculi sebagai enunjang dakwah, hal ini bisa dilihat dari bahwa hampir semua rumah ibadah, sekolah dan dan lembaga-lembaga keagamaan lainya di bangun di atas tanah wakaf, dan suatu kemajuan yang sangat signifikan bagi umat Islam, ketika dikeluarkan Undang-Undang Perwakafan yaitu UU No. 41 tahun $2004^{4}$

Mengingat luasnya aspek dan fungsi yang dimiliki tanah Suroso, G.H. dan Drs. Nico Ngani, S.H. MSSW menyatakan :

"Tanah sudah dan akan tetap menduduki tempat utama dalam sistem nilai (value system) manusia. Hanya saja, atas dasar kondisi dan kepentingan tertentu, ia mengejewantah dalam bentuk tertentu pula, yaitu : ekonomis, politis, yurudis, sosiologis, religius. Urutannya biss dipertukarkan tergantung aspek mana yang bendak lebih ditonjolkan." 5

Melihat lebih jauh kepada aspek dakwah, dalam prakteknya ternyata di Indonesia tidak sedikit badan-badan atau lembaga dakwa yang mempunyai hak milik atas tanah (selanjutnya disebut mempunyai tanah). Organisasi keagamaan dan sosial yang dapat mempunyai tanah dimana tanah-tanah yang dimilikinya tersebut digunakan sebagai tempat ibadah, Sekolah, gedung pertemuan dan lain-lain tempat sebagai wadah pembinaan Umat Islam atau dakwah.

Hal ini sebenarnya sesuai dengan isi dari Pasal 49 ayat (1) UUPA No 5 Tahun 1960 yang menyebutkan :

3 Abdullah bin Abdurrahman Al Bassam, Syarah Bulughul Maram, Jakarta: Pustaka Azzam, Jil 5, 2006), 119

${ }^{4}$ Bashlul Hazami, Peran dan Aplikasi wakaf dalam mewujudkan kesejabtraan umat di Indonesia, (Surabaya; Jurnal Analisis, Volume XVI, nomor 1, 2016),176.

${ }^{5}$ Suroso, NicoNgani, TinjauanYuridistentangPerwakafan Tanab Milik, (Yogyakarta: Liberty, 1984), 111. 
"Hak milik atas tanah badan-badan keagamaan dan sosial sepanjang dipergunakan untuk amal usaha dan kegiatan sosial diakui dan dilindungi. Badanbadan tersebut dijamin pula akan memperoleh tanah yang cukup untuk bangunan dan usahanya dalam bidang keagamaan dan sosial."

Pasal ini berarti memberikan jaminan kepada badan-badan keagamaan dan sosial untuk memiliki tanah dengan status hak milik asalkan tanah tersebut dipergunakan untuk kepentingan keagamaan. Tanah-tanah yang dimiliki oleh badan keagamaan dan lembaga dakwah merupakan harta benda (kekayaan) baginya, hingga dipelihara dan juga dicadangkan untuk keperluan umat di masa datang.

Di dalam Hukum Islam dikenal banyak cara untuk mendapatkan hak atas tanah. Perolehan dan peralihan hak atas tanah dapat terjadiantara lain melalui jual-beli, tukar menukar, hibah, infaq, sedekah, wakaf, wasiat, ihya ulmawat (membuka tanah baru). ${ }^{6}$

Perolehan atau peralihan yang dikenal dalam Hukum Islam tersebut, maka di kalangan umat Islam di Indonesia ternyata wakaf mendapat perhatian yang cukup besar, begitu juga dari pihak Pemerintah Republik Indonesia merasakan pentingnya masalah wakaf tersebut.

Menyadari arti pentingnya tanah wakaf tersebut, maka untuk lebih menjamin efektifnya pelaksanaan perwakafan tanah ini maka sudah barang tentu diperlukan adanya suatu pengawasan yang ketat. Menurut Pasal 13 peraturan pemerintah no. 28 tahun 19777 , maka pengawasan perwakafan tanah milik dan tata caranya diberbagai wilayah ditetapkan lebih lanjut oleh menteri agama.

Pada umumnya perwakafan tanah terjadi di daerah-daerah tingkat Kecamatan. Untuk memudahkan pengawasan diperlukan adanya administrasi yang tertib baik di tingkat Kecamatan, Kabupaten, Provinsi dan Pusat. Mengenai cara pengawasan menurut jalur timbal balik akan ditetapkan lebih lanjut oleh Menteri Agama. ${ }^{8}$

Hadirnya Undang-UndangRepublik Indonesia No.41 tahun 2004 tentang Wakaf, merupakan Undang-Undang yang dinantikan oleh segenap Bangsa Indonesia terutama yang memeluk agama Islam. Karena masalah perwakafan telah menjadi problem yang cukup lama dan belum ada undangundang yang secara khusus tentang wakaf, sehingga perwakafan di negeri kita kurang berkembang secara optimal. ${ }^{9}$ dengan adnaya Undang-Undang ini kendala-kendala saran dan prasarana dakwah diharapakan dapat teratasi

6 Al-Alabij. Adijani,Perwakafan Tanah di Indonesia dalamTeoridanPraktek, (Jakarta:RajawaliPers, 1989), 3-4.

${ }^{7}$ Http://www.bpn.go.id/Publikasi/Peraturan-Perundangan/Peraturan-

Pemerintah/peraturan-pemerintah-no-28-tahun-1977,17 Januari 2017

"RuchailisFahmi, "Pelaksanaan Sertifikasi Tanah Wakaf Di Kota Banjarmasin."

Tesis. (Program Pasca Sarjana universitas Diponegoro, Semarang, 2008), 8

${ }^{9}$ https://kepri.kemenag.go.id/files/kepri/file/file/Perpu/syvx1390190395.pdf ,

17 Januari 2017 
Pada dasarnya perwakafan tanah setidaknya harus memperhatikan dua aspek yaitu Pertama aspek legalitas sebuah tanah wakaf kedua aspek peruntukan tanah wakaf, aspek legalitas berkaitan dengan administrasi wakaf yang dilakukan oleh warga masyarakat tersebut maka diperlukan adanya tertib administrasi pertanahan. Oleh karena itu tanah yang di wakafkan tersebut selanjutnya di daftarkan melalui proses pendaftran tanah yang dilakukan oleh Badan Pertanahan Nasional. Pengaturan tentang Pendaftaran Tanah ini diatur dalam undang-undang tersendiri yaitu Undang-Undang No. 5 Tahun 1960 tentang Peraturan Dasar Pokok Agraria yang lebih dikenal dengan UndangUndang Pokok Agraria Pasal 49, serta sejumlah peraturan lain sesudahnya. ${ }^{10}$

Aspek peruntukan tanah wakaf akan menentukan untuk apa tanah wakaf tersebut akan digunakan apakah untuk kepentingan social atau untuk kepentingan dakwah seperti sekiolah atau non formal seperti Masjid dan tempat ibadah, kebiasaan memandang wakaf sebagai amal shaleh yang mempunyai nilai mulia di hadirat Tuhan ${ }^{11}$, akan tetapi harus mengedepankan asas yang lebih member manfaat,

pada saan ini dimana perkembangan teknologi dan informasi begitu kuat sampai kepelosok desa harus lah diinbangi dengan sarana dakwah baik secara formal seperti sekolah yang berdasrkan syari'at ataupun lembaga dakwa non formal seperti masjid dan tempat ibadah lainnya sebagai sarana menyampaikan dakwah Islam, perkembangan harus informasi yang tidak sejalan dengan perkembangan dakwah akan menyebabkan umat kehilangan kendali dalam menjalankan kehidupan beragama.

Dalam penelitian ini penulis akan berusaha melihat dan memberikan analisa sejauh mana keterlibatan tanah wakaf sebagai sarana dan sekaligus sebagai penunjang dakwah Islam, penelitian ini akan berfokus di Kecamatan Tebat Karai kabupaten Kepahiang provinsi Bengkulu, dimana dilokasi penelitian antosias masyarakat untuk berwakaf sangat bagus hal ini terbukti terdapat sebanyak 35 tanah wakaf dari 14 desa,. ${ }^{12}$ penelitian ini juga akan melihat bagaimana status legalitas tanah wakaf yang diperuntukan sebagai sarana dakwa di loakasi penelitian.

Berdasarkan uraian diatas, penulis akan melakukan sebuah penelitian terkait dengan peruntukan tanah sebagai sarana dakwah dan menuangkannya dalam sebuah penelitian yang berjudul : "Pemanfaatan Tanah Wakaf Sebagai Prasarana Dakwa Di Kecamatan Tebat Karai”. Berdasarkan latar belakang tersebut di atas, maka permasalahan yang akan diajukan oleh penulis adalah Bagaimana pemanfaatan tanah wakaf sebagai sarana dakwah di Kecamatan Tebat Karai? Sedangkan, tujuan penelitian untuk mengetahui bagaimana pemanfaatan tanah wakaf bagi kepentingan sarana dakwah di Kecamatan Tebat Karai.

${ }^{10}$ Peragin Efendi, Hukum Agraria Indonesia, (Jakarta: Rajawali Pers, 1991), 95.

${ }^{11}$ Ahmad DjunaididanThobib Al-Asyhar, Meniju Era WakafProduktif,(Jakarta: Mumtaz Publishing, 2005), 57.

${ }^{12}$ Arsip KUA Kecamatan Tebat Karai tahun 2016 


\section{Metode Penelitian}

1. Jenis Penelitian

Jenis penelitian ini adalah penelitian lapangan (field research). bertujuan untuk memecahkan masalah-masalah praktis dalam masyarakat. ${ }^{13}$ Penelitian ini berada pada masyarakat di wilayah Kecamatan Tebat Karai, Kabupaten Kepahiang dengan memfokuskan pada aspek tanah wakaf yang dijadikan saran dakwah.

2. Sumber Data

Adapun untuk memperoleh data penelitian yang objektif dan ilmiah, penelitian ini akan menggunakan metode sebagai berikut:

a. Sumber Data Primer

Adalah data yang diperoleh langsung dari subyek penelitian dengan mengenakan pengambilan data langsung pada subyek sebagai sumber informasi yang dicari. ${ }^{14}$

Sebagai data primer pada penelitian ini adalah Nadzir yang berada di wilayah Kecamatan Tebat Karai baik yang menjadi Nazir wakaf sebagai sarana dakwah atau Nazir wakaf sebagai tempat social lainnya.

b. Sumber Data Sekunder

Sumber data skunder adalah data yang diperoleh dari pihak lain, tidak langsung dari subyek penelitian.Peneliti menggunakan data ini sebagai pendukung dari data primer yang peneliti dapat secara langsung dari masyarakat atau dari lembaga-lembaga pemerintahan.

3. Teknik Pengumpulan Data

Penelitian ini adalah penelitian kualitatatif dengan paradigma naturalistik. Penelitian dengan konteks naturalistik dengan harapan makna yang di angkat dari penelitian tersebut memang dari konteksnya bukan dari konsep prapenelitian. Maka dalam memperoleh data, peneliti menggunakan metode

a. Metode Observasi

Metode Observasi yakni teknik pengumpulan data di mana peneliti mengadakan pengamatan secara langsung atau tidak langsung lokasi penelitian di kecamatan Tebat Karai Kabupaten Kepahiang,. ${ }^{15}$

Observasi atau pengamatan, peneliti gunakan untuk mencari data tanah wakaf baik dari lembaga pemerintahan ataupun dari penduduk dari objek penelitian. 1995), 28.

${ }^{13}$ Mardalis, Metode Penelitian Suatu Pendekatan Proposal, (Jakarta: PT. Bumi Aksara, ${ }^{14}$ SaifuddinAzwar, Metodepenelitian,( Yogyakarta: PustakaPelajar, Cet. 1, 1998), 91.

${ }^{15}$ Burhan Ashshofa, Metode Penelitian Hukum, (Jakarta : Rineka Cipta, 1996), 26. 
b. Metode Wawancara

Wawancara adalah merupakan pertemuan dua orang untuk bertukar informasi dan ide melalui tanya jawab, sehingga dapat dikonstruksikan makna dalam suatu topik tertentu.

Wawancara digunakan sebagai teknik pengumpulan data apabila peneliti ingin melakukan studi pendahuluan untuk menemukan permasalahan yang harus diteliti, tetapi juga apabila peneliti ingin mengetahui hal-hal dari responden yang lebih mendalam. Teknik pengumpulan data ini mendasarkan diri pada laporan tentang diri sendiri atau setidak-tidaknya pada pengetahuan dan atau keyakinan pribadi. ${ }^{16}$

Metode wawancara di gunakan untuk menggali data dari sumber aslinya yakni wakif atau nadzir di Kecamatan Tebat Karai. Penggunaan metode ini untuk mengetahui lebih jauh tentang pengetahuan,pemahaman, sikap dan pola perikelakuan masyarakat dalam mewakafkan tanah dan mengelola tanah wakaf sertifikasi tanah wakaf.

\section{Hasil dan Pembahasan}

A. Pengertian dakwah

Islam adalah agama yang sempurna dan umatnya adalah umat terbaik sepanjang menjalankan amar ma'ruf nahi mungkar sebagai firman allah SW'T dalam surat Ali Imran ayat 104 yang artinya : "kamu (umat Islam) adalah umat terbaik yang dilabirkan untuk manusia (karena kamu) menyurub kepada yang mak'ruf dan mencegah dari yang mungkar dan beriman kepada allah..."

Secara etimologi kata dakwah merupakan bentuk masdar dari kata da'a (fil madi) yad'u (fil' mudhadri') yang maknanya adalah memanggil atau mengundang, mengajak mendorong dan memohon.

Dakwah menurut terminology mengadung beberapa arti bermacam pengertian di antara pendapat ahli ilmu dakwa adalah :

1. Amarullah Ahmad dakwah adalah mengadakan serta memberikan arahan untuk perubahan, merubah struktur masyarakat dan budaya dari kezholiman dan kepada keadilan, keterbelakangan ke arah kemajuan (kecerdasan), kemiskinan kearah kemakmuran yang semunya dalam rangka meningkatkan derjat masnuia dan masyarakat kearah puncak kemanusiaan. (Amrullah Ahmad; 1983. H 17)

2. Hamzah Ya'qub, dakwah adalah mengajak umat manusia dengan hikamh kebijaksanaan untuk mengikuti petunjuk Allah dan Rasul-Nya (Ya'qub, 1982. H, 13)

3. Asep Muhidin dakwah adalah upaya kegiatan mengajak atau menyeru umat manusia agar berada di jalan allah yang sesuai fitrah dan kehanifannya secara integral.(Asep Muhidin: 2002.h. 19)

4. Asmuni Syukir, memebrikan defenisi bahwa dakwah adalah suatu usaha mempertehankan, melestarikan dan menyempurnakan umat manuisa

${ }^{16}$ Sugiyono, Metode Penelitian Kuantitatif Kualitatif Dan $\mathrm{R}$ \& D, (Bandung: Alfabeta, 2014), 231 
agar mereka tetap beriman kepada allah, dengan menjalankan syari'at Nya sehingga mereka menjadi manuisa yang hidup bahagia di dunia maupun di akhirat (Syukir, 1983.h. 20)

Dari beberapa defenisi yang diutarakan oleh para ilmuan dakwah kita dapat melihat betapa luas cakupan dari dakwah tersebut yang pada intinya dapat ita ambil adalah berupa upaya atau kegiatan mengajak manusia kembali kepada jalan dan syari'at Allah dalam sega aspek kehidupan dunia agar syari'at agama Allah menjadi fatokan dalam beraktivitas duniawi dan ukhrawi.

a. Tujuan dakwah.

Dakwa merupakan tugas muliah setiap orang yang sanggup sebatas kemampuannya, oleh sebeb tiu agar dakwa mencapa sasaran yang optimal maka harus di pahami apa tujuan dakwa yang sebenarnya, setidaknya da dua tujuan dakawan yaitu itu tujuan umum dan tujuan khusus.

1. Tujuan umum.

Tujuan dakwa secara umum adalah membawa amusia dari lembah kesesatan kepada cahaya yang terang bendederang (hidayah Alla), dari dari lembah kemusrikan kepada cahaya tauhid yang mendatangkan kebahagiaan duniawi dan ukhrawi. ${ }^{17}$

Pemahaman tujuan dalwah seperti ini dapat kita ambil dari Qur'an surat An-Nahl :125)

Serulah (manusia) kepada jalan Tuhan-mu dengan hikmah dan pelajaran yang baik dan bantablab mereka dengan cara yang baik. Sesunggubnya Tubanmu Dialah yang lebih mengetahui tentang siapa yang tersesat dari jalan-Nya dan Dialah yang lebih mengetahui orang-orang yang mendapat petunjuk.

2. Tujuan khusu.

Tujuan khusu dakwah adalah khusus dari tujuan umum yang dijabarkan secara rinci, bahkan bisa dikatakan sebagai bentuk khusus (operasional) dari aktipitas dakwah, tujuan khusu dakwah setidaknya dapat dibagi kedalam beberapa tujuan ${ }^{18}$ yakni :

1. Kepada umat Islam secara internal agar meningkatkan ketakwaan kepada Allah SW'T.

2. Menstabilkan mental bagi manusia yang masih baru memeluk agama Islam.

3. Mengajak non muslim agar manusia beriman kepada Allah SWT.

4. Mendidik dan mentarbiayah anak-r tidak menyimpang dari fitra nya.

17 Awaludin Pimary, Metodologi Dakwah, 2006. 8

${ }_{18}$ Asmuni Syukir; 1983. 54 
3. Elemen dakwa.

Dakwah tidak dapat bergerak secara sendiri-sendiri melainkan harus bersinergi dengan pihak terkait demi terciptanya tujuan dakwah baik secara umum ataupun secara khsus. Elemen dakwah yang harus ada dalam setiap aktipitas dakwah setinya ada tiga yaitu Da'I, (subjek dakwah), Mad'u (objek dakwa)dan maddatu al dakwah ( materi dakwah), sedangkan unsure-unsur lain yang dapat mempengaruhi proses dakwah seperti media dakwah dan metode dakwah, ${ }^{19}$ tetapi satu elemen yang tidak kalah penting adalah prasarana dakwah itu sendiri baik yang berbentuk formalitas atau non formal, hal yang terakhir ini lah yang akan menjadi focus pembahasa penulisan ini.

a. Da’i menurut bahasa kata Da’i berasal dari bahasa Arab bentuk Muzakkar yang berari orang yang mengajak, dan dalam bentuk Muannast disebut Da'iyah, kata ini sering disebut dengan sebutan Mubaligh (orang yang menyampaikan ajaran agama) ${ }^{20}$. Dmerupakan pelaku dakwah baik secara lisan ataupun tulisan, apakah melalui perbuatan atau melalui ucapan, secara berkelompok, individu dan organisasi atau lembaga (Azizi, 2004: 75)da'I dalam dakwahnya sangat dituntut untuk memahami stuasi social masyarakat dan tranformasi social baik secara kultur maupun keagamaan. Disamping itu seorang da'I harus mempunyai kepribadian yang baik secara jasmani bersifat, bersikap dan kemampuan diri. Ketiga unsur tersebut merupakan keseluruhan kpribadian yang harus dimiliki ${ }^{21}$ sedangkan kpribadian yang bersifat rohani adalah beriman dan bertakwa kepada Allah, sifat ini merupakan dasar utama pada aklak da'I, ahli tobat serta ahli ibadah.

b. Objek dakwah, ialah orang yang menjadi sasaran dakwah, yaitu semua manusia, sebagaiman firman allah SWT " dan kami tidak mengutus kamu, melainkan kepada kepada umat manusia selurubnya sebagai pembawa berita gembira dan sebagai pemberi peringatan, tetapi kebanyakan manusia tidak mengetahui", (qur'an surat As-Saba' ayat 28).

Menurut pandangan Abdul Munir Mulkhan, bahwa objek dakwah ada dua sasaran, yaitu umat dakwah dan umat ijabah umat dakwah yang dimaksud adalah masyarakat luas non muslim sementara umat iajabah adalah mereka yang sudah menganut agama Islam, kepada manusia yang belum beragama Islam dakwah bertujuan untuk mengajak mereka mengikuti agama Islam, sedangkan bagi orang yang sudah beragama Islam dakwah bertujuan meningkatkan kwalitas iman, Islam dan ihsan.

${ }^{19}$ Dzikron Abdullah, 1986, 40

${ }^{20}$ St. Rahmatilah: Kepribadian seorang Da’i. (Jurnal Bimbingan Penyuluhan Islam Volume 6, nomor 2, 2019), 2.

${ }^{21}$ Faizah, 90. 
c. Materi dakwah (maddatu al Dakwah) maddah adalah pesan yang disampaikan da'I kepada mad'u yang mengandung kebenaran dan kebaikan bagi manusia yang bersumber dari syari'at. Allah memerintahkan kepada Nabi Muhammad SAW untuk memilih materi dakwah yang sesuai dengan stuasi dan kondisi objek dakwah,namun materi tetap tidak bergesar dari ajaran Islam.

d. Prasarana dakwah, secara istilah prasarana adalah bahan material atau perangkat keras, 22 menurut kamus Besar Bahasa Indonesia KBBI prasarana adalah segala sesuatu yang menjadi penunjang utama terselenggaranya suatu proses (usahha, pembangunan, proyek), dengan daemikian dapat disimpulkan bahwa prasarana adalah penunjang pokok dari kelangsungan dakwah yang berbentuk material atau bangunan yang dapat dilihat secara pisik dimana dakwah itu diadakan, dengan demikian prasarana dakwah setidaknya dapat disifati kepada dua sifat, pertama prasarana yang bersifat formal seperti sekolah madrasah yang kegiatan dakwah terprogram secara sistimatis baik materi ataupun waktunya, kedua prasarana yang bersifat non formal seperti kegiatan dakwah yang tidak terprogram secara sistimatis baik dari waktu ataupun materi dakwanya serta objek dakwahnya, seperti dakwah yang dilakukan di masjid, musollah dan tempat ibadah lainnya yang semua objek dakwah bisa saja mengikutinya, lain halnya dengan prasarana dakwah yang bersifat formal objek dakwahnya, waktu dan tempatnya serta pendakwanya sudah diatur sedemikian rupa hal ini biasanya dilakukan di sekolah, madrasah pondok pesantren dan tempat belajar yang lainnya.

B. Pengertian wakaf

Kata “wakaf” berasal dari bahasa Arab "al-Waqf”, bentuk masdar dari "Waqafa-Yaqifu-Waqfan. Kata al-waqfsemakna denganal-habs bentuk masdar dari "Habasa-Yabbisu-Habsan" artinya menahan. ${ }^{23}$

Dalam pengertian istilah, ulama berbeda redaksi dalam memberi rumusan. Wakaf adalah menahan harta dan memberikan manfaatnya di jalan Allah. Ahmad Rofiq mengatakan dalam Masu'ab Fiqh umar ibn al-Khattab disebutkan, wakaf adalah menahan asal harta dan menjalankan hasil (buahnya). ${ }^{24}$

22 Pius.a Partanto \& M. dahlan al Barry, Kamus Ilmiah Populer (Surabaya, Arkola, 2001), 624.

${ }^{23}$ Sayyid Sabiq, Fiqh al-Sunah, juz 3. (Beirut: Dar al-Fiqr,tt), 515

24 Ahmad Rofiq, Hukum Perdata Islam Indonesia, (Jakarta: PT. Raja Grafindo Persada, 1995), 490 
Dalam hukum figh, istilah tersebut berarti menyerahkan suatu hak milik yang tahan lama zatnya kepada seseorang atau nazhir (penjaga wakaf), atau kepada suatu badan hukum pengelola dengan ketentuan bahwa hasil atau manfaat digunakan kepada hal-hal yang sesuai dengan ajaran syari'at Islam.

Dari berbagai pengertian wakaf menurut bahasa di atas, maka dapat disimpulkan, bahwa al-habs maupun al-waqf sama-sama mengandung makna menahan, mencegah atau melarang dan diam. Di katakan menahan karena wakaf ditahan dari kerusakan, penjualan dan semua tindakan yang tidak sesuai dengan tujuan wakaf. Menurut istilahs, wakaf berarti berhenti atau menahan harta yang dapat diambil manfaatnya tanpa musnah seketika dan untuk penggunaan yang mubah, serta dimaksudkan untuk mendapatkan keridaan Allah swt. ${ }^{25}$

Para ahli fiqh berbeda dalam mendefinisikan wakaf menurut istilah, sehingga mereka berbeda pula dalam memandang hakikat wakaf itu sendiri. Berbagai pandangan tentang wakaf menurut istilah sebagai berikut:26

a. Abu Hanifah

Imam Abu Hanifah mendefinisikan wakaf dengann: "menahan materi benda orang yang berwakaf dan menyedekabkan manfaatnya untuk kebajikan.' 'Imam Abu Hanifah memandang akad wakaf tidak mengikat, dalam artian, bahwa orang yang berwakaf boleh saja mencabut wakafnya kembali dan boleh diperjualbelikan oleh pemilik semula. Dengan demikian, mewakafkan harta bagi Imam Abu Hanifah, bukan berarti menanggalkan hak milik secara mutlak. Menurutnya, akad wakaf baru bersifat mengikat apabila: ${ }^{27}$

1. Terjadi sengketa antara orang yang mewakafkan (wakif) dan pemelihara harta wakaf (nadzir), dan hakim memutuskan bahwa wakaf itu mengikat;

2. Wakaf itu dipergunakan untuk masjid;

3. Apabila benda wakaf itu dihubungkan dengan kematian si wakif yaitu wakaf wasiat.

b. Mazhab Maliki

Mazhab Maliki berpendapat bahwa wakaf itu tidak melepaskan harta yang diwakafkan dari kepemilikan wakif, namun wakaf tersebut mencegah wakif melakukan tindakan yang dapat melepaskan kepemilikannya atas harta tersebut kepada yang lain dan wakif 2009), 51.

${ }^{25}$ Rachmadi Usman, Hukum Perwakafan Di Indonesia, Jakarta: Sinar Grafika,

26Departemen Agama RI, Fiqh Wakaf, (Jakarta: Direktorat Pemberdayaan Wakaf, Dirjen Bimbingan Masyarakat Islam Cet. V, 2007), 2

${ }^{27}$ Abdul Azis Dahlan, Ensiklopedi Hukum Islam, (Jakarta: PT. Ichtiar Baru van Hoeve, Cet. 1, Jil. 6, 1996), 1905 
berkewajiban menyederhanakan manfaatnya serta tidak boleh menarik kembali wakafnya. Perbuatan si wakif menjadikan manfaat hartanya untuk digunakan oleh mustahiq (penerima wakaf), walaupun yang dimilikinya itu berbentuk upah, atau menjadikan hasilnya untuk dapat digunakan seperti mewakafkan uang. Wakaf dilakukan dengan mengucapkan lafadz wakaf untuk masa tertentu sesuai dengan keinginan pemilik. Dengan kata lain, pemilik harta menahan benda itu dari penggunaan secara pemilikan, tetapi membolehkan pemanfaatan hasilnya untuk tujuan kebaikan, yaitu pemberian manfaat benda secara wajar sedang benda itu tetap menjadi milik si wakif. Perwakafan itu berlaku untuk suatu masa tertentu, dan karenanya tidak boleh disyaratkan sebgaai wakaf kekal (selamanya). ${ }^{28}$

c. Mazhab Syafi'i dan Ahmad bin Hambal

Syafi'i dan Ahmad berpendapat bahwa wakaf adalah melepaskan harta yang diwakafkan dari kepemilikan wakif, setelah sempurna prosedur perwakafan. Wakif tidak boleh melakukan apa saja terhadap harta yang diwakafkan, seperti: perlakuan pemilik dengan cara pemilikannya kepada yang lain, baik dengan tukaran atau tidak. Jika wakif wafat, hata yang diwakfkan tersebut tidak dapat diwarisi oleh ahli warisnya. Wakif menyalurkan manfaat harta yang diwakfkannya kepada manquf 'alaih (yang diberi wakaf) sebagai sedekah yang mengikat, dimana wakif tidak dapat melarang penyaluran sumbangannya tersebut. Apabila wakif melarangnya, maka Qadli berhak memaksanya agar memberikannya kepada mauqu 'alaih. Karena itu mazhab Syafi'i mendefinisikan wakaf adalah: "Tidak melakukan suatu tindakan atas suatu benda, yang berstatus sebagai milik allah Swt. dengan menyedekahkan manfaatnya kepada suatu kebijakan (sosial)". ${ }^{29}$

d. Abu Yusuf dan Imam Muhammad

Mengartikan wakaf adalah penahanan pokok suatu benda di bawah hukum benda Tuhan Yang Maha Kuasa, sehingga hak pemilikan dari wakaf berakhir dan berpindah kepada Tuhan Yang Maha Kuasa untuk tujuan yang hasilnya dipergunakan untuk makhluk-Nya. ${ }^{30}$

e. Maulana Muhammad Ali

Wakaf berarti penetapan yang bersifat abadi untuk memungut hasil dari barang yang diwakafkan guna kepentingan orang seorang, atau yang bersifat keagamaan, atau untuk tujuan amal. ${ }^{31}$ 2008), 151

${ }^{28}$ Wahbah Zuhaili, Al-Fiqhu wa 'Adillatubu, (Damaskus: Dar al-Fiqkr al-Mu'ashir,

${ }^{29}$ Ibid, 153

30 Abdurrahman, Masalah Perwakafan Tanah Milik Dan Kedudukan Tanah Wakaf Di Negara Kita, (Bandung : P.T Citra Aditiya Bakti, 1994), 18

${ }^{31}$ Abdul Ghofur Anshori, Hukum dan Praktik Perwakafan di Indonesia, (Yogyakarta: Pilar Media, 2005), 12 
f. Jumhur Ulama

Wakaf adalah merupakan suatu harta yang mungkin dimanfaatkan selagi barangnya utuh, dengan putusnya hak penggunaan dari si wakif atau orang lain, untuk kebajikan yang semata-mata demi mendekatkan diri kepada Allah. ${ }^{32}$

g. Kompilasi Hukum Islam (KHI)

Dalam KHI, wakaf didefinisikan sebagai perbuatan hukum seseorang atau kelompok orang atau badan hukum yang memisahkan sebagian dari benda miliknya dan melembagakannya uantuk selamalamanya guna kepentingan ibadat atau keperluan umum lainnya sesuai dengan ajaran Islam.

Wakaf termasuk salah satu bentuk filantropi (kedermawanan), selain zakat, infaq dan sedekah yang senantiasa diharapkan pengamalannya, seperti terlihat dalam pesan-pesan ajaran Islam. Dengan demikian, berwakaf adalah perbuatan baik yang sangat dianjurkan agama.

Dari beberapa pengertian wakaf di atas dapat ditarik kesimpulan bahwa wakaf meliputi: 33

a) Harta benda milik seseorang atau kelompok.

b) Harta benda tersebut bersifat kekal zatnya, tidak habis apabila dipakai.

c) Harta tersebut kepemilikannya oleh pemiliknya.

d) Harta yang lepas kepemilikannya tersebut tidak bisa dihibahkan, diwariskan atau diperjualbelikan.

Manfaat dari harta benda tersebut adalah untuk kepentingan umum sesuai dengan ajaran agama Islam.

\section{Pemanfaatan Tanah Wakaf Sebagai Prasarana Dakwah di Kecamatan Tebat Karai}

a. Gambaran umum kecamatan tebat karai.

Tebat Karai adalah sebuah kecamatan di Kabupaten Kepahiang yang dibentuk sejak berdirinya Kabupaten Kepahiang pada 7 Januari 2004. Nama Kecamatan diambil berdasarkan nama sebuah kelurahan yang termasuk dalam wilayah kecamatan Tebat Karai ini. Wilayah ini terletak memanjang dengan pegunungan Bukit Barisan, posisi $101^{\circ} 45^{\prime}-103^{\circ}$ Bujur Timur dan $2^{\circ}$ 45' - $3^{0}$ 5' Lintang Selatan.

Secara geografis Kecamatan Tebat Karai memiliki luas wilayah 63.665 Ha yang terdiri dari permukiman, tanah perkebunan, tanah sawah, fasilitas umum dan lain-lain. ${ }^{34}$

${ }^{32}$ Abdurrahman, Op. Cit., 20

${ }^{33}$ Ahmad Rofiq, Op. Cit., 491

${ }^{34}$ Dokumentasi Kantor Camat Tebat Karai, 11 
Kecamatan Tebat Karai merupakan bagian dari 8 kecamatan yang berada di wilayah Kabupaten Kepahiang, Kecamatan Tebat Karai sendiri terdiri dari 13 desa dan 1 kelurahan yaitu:

1. Desa Taba Air Pauh;

2. Desa Penanjung Panjang;

3. Desa Penanjung Panjang Atas;

4. Desa Peraduan Binjai;

5. Desa Tebing Penyamun;

6. Desa Talang Karet;

7. Desa Tertik;

8. Desa Taba Santing;

9. Desa Taba Saling;

10. Desa Tapak Gedung;

11. Desa Karang Tengah;

12. Desa Sinar Gunung;

13. Desa Nanti Agung; dan

14. Kelurahan Tebat Karai.

Pusat Kecamatan Tebat Karai ialah desa Tebat Karai yang jarak tempuh antara Tebat Karai dengan kota Kabupaten adalah $\pm 9 \mathrm{Km}$, dengan kondisi jalan aspal betol dalam keadaan baik dan dapat ditempuh dengan transportasi yang lancar.

Sedang kan batas-batas alami wilayah Kecamatan Tebat Karai adalah sebagai berikut: 35

a. Sebelah Timur berbatasan dengan Kecamatan Bermani Ilir

b. Sebelah Barat berbatasan dengan Kecamatan Kepahiang

c. Sebelah Utara berbatasan dengan Kecamatan Kabawetan

d. Sebelah Selatan berbatasan dengan Kecamatan Seberang Musi

Berdasarkan data dari Kecamatan Tebat Karai Jumlah penduduk Hingga akhir Maret berjumlah 18.020 jiwa yang hampir seluruhnya atau 99.99\% beragama Islam. Jumlah penduduk laki-laki 8.900 jiwa dan perempuan 9.120 jiwa. Dilihat dari jumlah pemeluk agama, yang beragama Islam berjumlah 18.019 jiwa, agama Kristen 1 Jiwa.

Dilihat dari macam suku bangsa (etnis), penduduk kecamatan Tebat Karai dari beberapa suku Bangsa, yakni suku Rejang, suku Serawai, suku Lembak, suku Jawa, suku Minang. Yang paling dominan adalah suku Rejang, karena hampir 80\% penduduk di Kecamatan Tebat Karai adalah Penduduk Reajang asli. Sarana peribadatan di Kecamatan Tebat Karai bisa dilihat dari 25 jumlah tempat ibadah yang ada yakni, Masjid 14 buah dan Musholla 11 buah. ${ }^{36}$ 
1. Jumlah tanah wakaf di kecamatan Tebat Karai.

Data Tanah Wakaf di Kecamatan Tebat Karai 2017

Table 01

\begin{tabular}{|c|l|c|c|c|}
\hline NO & NAMA DESA & $\begin{array}{l}\text { Jumlah Tanah } \\
\text { Wakaf }\end{array}$ & $\begin{array}{l}\text { Belum } \\
\text { AIW }\end{array}$ & Ket \\
\hline $\mathbf{1}$ & \multicolumn{1}{|c|}{$\mathbf{2}$} & $\mathbf{3}$ & $\mathbf{6}$ & $\mathbf{7}$ \\
\hline 1 & Taba Air Pauh & 3 & - & \\
\hline 2 & $\begin{array}{l}\text { Penanjung } \\
\text { Panjang }\end{array}$ & 2 & 2 & \\
\hline 3 & $\begin{array}{l}\text { Penanjung } \\
\text { Panjang Atas }\end{array}$ & 2 & - & \\
\hline 4 & $\begin{array}{l}\text { Peraduan } \\
\text { Binjai }\end{array}$ & 3 & - & \\
\hline 5 & $\begin{array}{l}\text { Tebing } \\
\text { Penyamun }\end{array}$ & 1 & - & \\
\hline 6 & Talang Karet & 3 & - & \\
\hline 7 & Tertik & 3 & - & \\
\hline 8 & Taba Santing & 1 & - & \\
\hline 9 & Taba Saling & 3 & - & \\
\hline 10 & Nanti Agung & 4 & - & \\
\hline 11 & Sinar Gunung & 2 & - & \\
\hline 12 & Karang Tengah & 2 & - & \\
\hline 13 & Tapak Gedung & 2 & - & \\
\hline 14 & $\begin{array}{l}\text { Kel. Tebat } \\
\text { Karai }\end{array}$ & Jumlah & $\mathbf{3 5}$ & \\
\hline
\end{tabular}




\section{Ket : AIW adalah Akta Ikrar Wakaf}

Dari table 01 diatas dapat kita lihat bahwa penyebaran tanah wakaf di kecamatan Tebat Karai hampir merata ada pada setiap desa, dari 35 objek wakaf di kecamtan Tebat Karai ada empat objek yang berada pada satu desa dan hal ini manggambarkan tinggi nya kesadaran serta minat masyarakat kecamatan Tebat Karai untuk berwakaf tanah.

\section{Laporan Pembagian dan peruntukan Tanah Wakaf'Tahun 2017}

Table 02

\begin{tabular}{|c|l|c|c|c|c|c|}
\hline No & Desa & Masjid & Musholla & Makam & Sekolah & Jumlah \\
\hline $\mathbf{1}$ & \multicolumn{1}{|c|}{$\mathbf{2}$} & $\mathbf{3}$ & $\mathbf{5}$ & $\mathbf{6}$ & $\mathbf{7}$ \\
\hline 1 & Taba Air Pauh & 1 & 1 & 1 & & $\mathbf{3}$ \\
\hline 2 & Penanjung Panjang & 1 & & 1 & & $\mathbf{2}$ \\
\hline 3 & $\begin{array}{l}\text { Penanjung Panjang } \\
\text { Atas }\end{array}$ & 1 & 1 & & & $\mathbf{2}$ \\
\hline 4 & Peraduan Binjai & 1 & 1 & 1 & & $\mathbf{3}$ \\
\hline 5 & Tebing Penyamun & 1 & & & & $\mathbf{1}$ \\
\hline 6 & Talang Karet & 1 & 1 & 1 & & $\mathbf{3}$ \\
\hline 7 & Tertik & 1 & 1 & 1 & & $\mathbf{3}$ \\
\hline 8 & Taba Santing & 1 & & & & $\mathbf{1}$ \\
\hline 9 & Taba Saling & 1 & 1 & 1 & & $\mathbf{3}$ \\
\hline 10 & Nanti Agung & 1 & 1 & 1 & 1 & $\mathbf{4}$ \\
\hline 11 & Sinar Gunung & 1 & 1 & & & $\mathbf{2}$ \\
\hline 12 & Karang Tengah & 1 & 1 & & & $\mathbf{2}$ \\
\hline 13 & Tapak Gedung & 1 & 1 & & & $\mathbf{2}$ \\
\hline 14 & Kel. Tebat Karai & 1 & 1 & 1 & 1 & $\mathbf{2}$ \\
\hline & Jumlah & $\mathbf{1 4}$ & $\mathbf{1 1}$ & $\mathbf{2}$ & & \\
\hline
\end{tabular}

Bila di lihat dari table 02 di atas yang berkaitan dengan luas dan peruntukan tanah wakaf maka dapat disimpulkan, bahwa peruntukan tanah wakaf terpokus pada empat peruntukan yaitu masjid, mushola pemakaman umum dan sekolah, dengan rincian peruntukan untuk Masjid sebanyak 14 lokasi, 
musholla 11 lokasi, Pemakaman Umum 8 lokasi dan sekolah 2 lokasi, dengan demikian minat masyarakat dalam berwakaf masih terpokus pada Tempat ibadah Masjid dan Mushalla, sementara yang paling sedikit adalah untuk sarana pendidikan sekolah formal.

Keberadaan tanah wakaf yang secara spesifik yang diperuntukan untuk pengembangan dakwa seperti Lembaga Dakwa atau yayasan yang khusu bergerak di bidang dakwa belum lagi ada.

\section{Data luas dan peruntukan Tanah Wakaf Di Kecamatan Tebat Karai}

\section{Table 03}

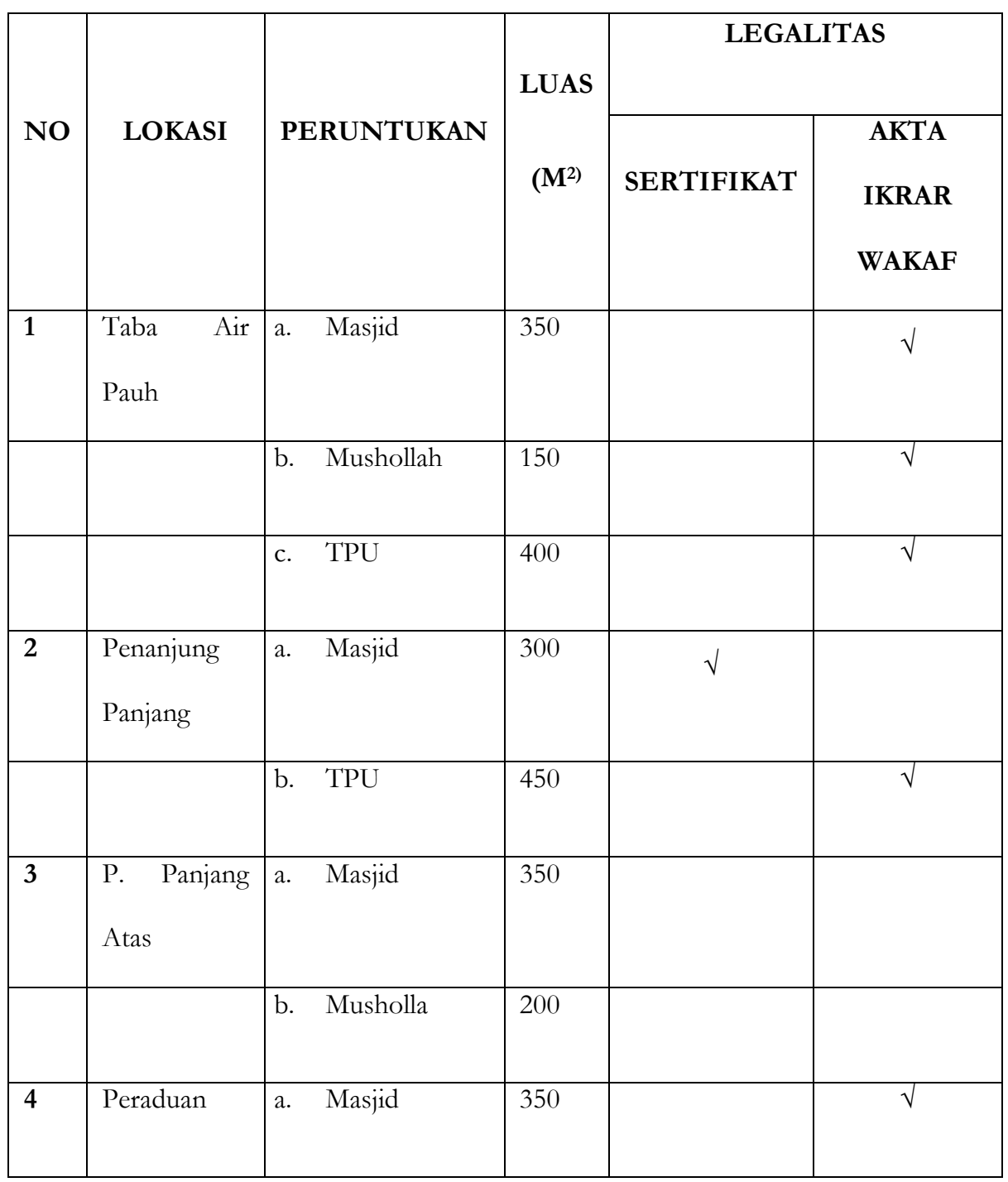


172 Jurnal Dakwah dan Komunikasi. Vol 5 no 2, 2020

\begin{tabular}{|c|c|c|c|c|c|}
\hline & Binjai & & & & \\
\hline & & b. Musholla & 150 & & $\sqrt{ }$ \\
\hline & & c. TPU & 400 & & $\sqrt{ }$ \\
\hline 5 & $\begin{array}{l}\text { Tebing } \\
\text { Penyamun }\end{array}$ & a. Masjid & 300 & & $\sqrt{ }$ \\
\hline 6 & Talang Karet & a. Masjid & 350 & $\sqrt{ }$ & \\
\hline & & b. Musholla & 150 & & $\sqrt{1}$ \\
\hline & & c. TPU & 300 & & $\sqrt{ }$ \\
\hline 7 & $\begin{array}{ll}\text { Kel. Tebat } \\
\text { Karai }\end{array}$ & a. Masjid & 350 & & $\sqrt{ }$ \\
\hline & & b. Musholla & 150 & & $\sqrt{ }$ \\
\hline & & c. TPU & 400 & & $\sqrt{ }$ \\
\hline & & d. Sekolah & 3600 & & $\sqrt{ }$ \\
\hline 8 & Taba Santing & a. Masjid & 300 & & $\sqrt{ }$ \\
\hline 9 & Taba Saling & a. $\quad$ Masjid & 350 & & $\sqrt{ }$ \\
\hline & & b. Musholla & 150 & & $\sqrt{ }$ \\
\hline & & c. TPU & 450 & & $\sqrt{ }$ \\
\hline 10 & Nanti Agung & a. Masjid & 400 & & $\sqrt{ }$ \\
\hline
\end{tabular}




\begin{tabular}{|c|c|c|c|c|c|}
\hline & & b. Musholla & 150 & & $\sqrt{ }$ \\
\hline & & c. TPU & 350 & & $\sqrt{ }$ \\
\hline & & d. Sekolah & 3000 & $\sqrt{ }$ & \\
\hline 11 & $\begin{array}{l}\text { Sinar } \\
\text { Gunung }\end{array}$ & a. Masjid & 300 & & $\sqrt{ }$ \\
\hline & & b. Musholla & 150 & & $\sqrt{ }$ \\
\hline 12 & $\begin{array}{l}\text { Karang } \\
\text { Tengah }\end{array}$ & a. Masjid & 350 & & $\sqrt{ }$ \\
\hline & & b. Musholla & 150 & & $\sqrt{ }$ \\
\hline 13 & $\begin{array}{l}\text { Tapak } \\
\text { Gedung }\end{array}$ & a. Masjid & 350 & & $\sqrt{ }$ \\
\hline & & b. Musholla & 150 & & $\sqrt{ }$ \\
\hline 14 & Tertik & a. Masjid & 300 & & $\sqrt{ }$ \\
\hline & & b. Musholla & 150 & & $\sqrt{ }$ \\
\hline & & c. TPU & 400 & & $\sqrt{ }$ \\
\hline
\end{tabular}

Untuk luas tanah wakaf secara keseluruhan seperti yang tergambar pada table di atas kita dapat simpulkan bahwa mekipun peruntukan untuk sekolah hanya dua buah objek tetapi luas secara keseluruhan sebesar $6.600 \mathrm{~m} 2$, dengan 
demikian luas tanah wakaf untuk sekolah atau pendidikan formal cukup menggembirakan meskipun hanya terdapat dua lokasi.

Dari keseluruhan data tanah wakaf di Kecamatan Tebat Karai dapat disimpulkan bahwa ada minat yang tinggi dari masyarakat untuk mewakaf kan tanah mereka untuk dipergunakan sebagai kepentingan umat meskipun disatu sisi harga dan peruntukan tanah di kecamatan Tebat Karai semangkin tinggi hal ini disebabkan sebagain besar masyarakat Tebat Karai berfrofesi sebagai petanai dan menggantungkan hidup mereka pada lahan pertanian.

Tingginya masyarakat Kecamatan tebat karai untuk mewakafkan tanah mereka untuk kepentingan umat merupakan peluang besar bagi umat Islam terutama aktivis dakwa untuk mengambil langkah yang tepat agar minat masyarakat yang begitu tinggi untuk berwakaf dapat disalurkan untuk kepentingan dakwa yang lebih terprogram, hal ini mengingat belum adanya Lembaga dakwa yang secara khusus berdiri di Kecamatan Tebat Karai yang menggunakan tanah wakaf.

Meskipun belum adanya pemanfaatan tanah wakaf secara spesifik/khusu untuk lembaga dakwah tetapi pada umumnya sudah pemanfaatan tanag wakaf untuk kepentingan dakwa dan umat seperti Masjid, Mushalla dan Sekolah. Hal ini bermakna secara umum tanah wakaf di kecamatan Tebat Karai sudah diperuntukkan untuk kepentingan dakwah meskipun belum lagi ada tanah wakaf yang diperuntukkan untuk Lembaga dakwa secara khsus, pada prinsipnya Mesjid dan Mushalla serta sekolah-sekolah dan madrasah adalah bentuk lembaga dakwah secara umum.

\section{Kesimpulan}

Dakwa merupakan urat nadi agama Islam dan misi Rasul SAW adalah menyampaikan dakwah (Tabligh) kepada seluruh umat manusia, oleh sebab itu tugas setiap muslim adalah meneruskan misi Rasulullah sebagai pembawa dakwa dan rahmat bagi seluruh alam.

Dakwah merupakan kegiatan secara pisik dan non pisik, untuk kelancaran dakwah sangat dibutuhkan sarana dan prasarana dakwah karena prasarana merupakan kebutuhan yang mendasar tercapainya dakwah yang berkwalitas, prasarana dakwah yang biasanya berupa bangunan pisik memerlukan lahan sebagai tempat berdirinya prasarana dakwah tersebut, salah satu solusinya adalah tanah wakaf, tanah wakaf merupakan salah satu solusi untuk terciptanya prasaran dakwah bagi meningkatkan aktipitas dakwah.

Peruntukan tanah wakaf yang diperuntukan bagi kepentingan dakwah di kecamatan Tebat karai sudah membanggakan karena tanah wakaf tersebut berupa untuk pembangunan tempat ibadah seperti Masjid, mushlla dan sekolah serta tempat pemakaman Umum, akan tetapi belum ada peruntukan tanah wakaf yang khsus untuk perkegerakan dakwah atau untuk Lembaga dakwah. 


\section{Daftar Pustaka}

\section{$\underline{\text { Sumber buku }}$}

Abdurrahman, Masalah Perwakafan Tanah Milik Dan Kedudukan Tanah Wakaf Di Negara Kita, (Bandung : P.T Citra Aditiya Bakti, 1994)

Anshori, Abdul Ghofur. Hukum dan Praktik Perwakafan di Indonesia, (Yogyakarta: Pilar Media, 2005)

Al-Asyhar, Ahmad DjunaididanThobib, Menuju Era WakafProduktif,Jakarta: Mumtaz Publishing, 2005),

Adijani, Al-Alabij,Perwakafan Tanah di Indonesia dalamTeoridanPraktek, (Jakarta:RajawaliPers, 1989)

Al Bassam, Abdullah bin Abdurrahman, Syarah Bulughul Maram, (Jakarta: Pustaka Azzam, Jil 5, 2006)

Ashshofa, Burhan. Metode Penelitian Hukum, (Jakarta : Rineka Cipta, 1996)

Azwar,Saifuddin. Metodepenelitian,( Yogyakarta: PustakaPelajar, Cet. 1, 1998)

Departemen Agama RI, Figh Wakaf, (Jakarta: Direktorat Pemberdayaan Wakaf, Dirjen Bimbingan Masyarakat Islam Cet. V, 2007)

Dahlan, Abdul Azis Ensiklopedi Hukum Islam, Jakarta: PT. Ichtiar Baru van Hoeve, Cet. 1, Jil. 6, 1996)

Efendi, Peragin, Hukum Agraria Indonesia, (Jakarta: Rajawali Pers, 1991)

Hafiduddin, Didin, Dakwah Aktual(Jakarta Geme Insani Press.cet. 3. hal. 76. Tahun 1998.

Mardalis, Metode Penelitian Suatu Pendekatan Proposal, (Jakarta: PT. Bumi Aksara, 1995)

Pius.a Partanto \& M. dahlan al Barry. Kamus Ilmiah Populer. Arkola. Surabaya. 2001.

Rofiq, Ahmad. Hukum Perdata Islam Indonesia, (Jakarta: PT. Raja Grafindo Persada, 1995)

Suroso, NicoNgani, Tinjauan Yuridis tentang Perwakafan Tanah Milik, (Yogyakarta: Liberty,1984)

Sugiyono, Metode Penelitian Kuantitatif Kualitatif Dan, (Bandung: Alfabeta, 2014)

Sabiq, Sayyid. Fiqh al-Sunah, juz 3. (Beirut: Dar al-Fiqr,tt)

Usman, Rachmadi. Hukum Perwakafan Di Indonesia, (Jakarta: Sinar Grafika, 2009), 
Zuhaili, Wahbah. Al-Fiqhu wa 'Adillatuhu, (Damaskus: Dar al-Fiqkr al-Mu'ashir, 2008)

\section{Sumber Jurnal}

Hazami, Bashlul, Peran dan Aplikasi wakaf dalam mewnjudkan kesejabtraan umat di Indonesia, Surabaya; jurnal Analisis, Volume XVI, nomor 1, hal.176. th. 2016.

Nur, Ahmad: Perayaan Gerbeg Besar Demak Sebagai Sarana Religi dalam Komunikasi Dakwah, Jurnal At Tabsyir STAIN Kudus, 2015

Rahmatilah: St. Kepribadian seorang Da’i. Jurnal Bimbingan Penyuluhan Islam Volume 6, nomor 2, 2019

\section{Sumber Internet}

Http://www.bpn.go.id/Publikasi/Peraturan-Perundangan/PeraturanPemerintah/peraturan-pemerintah-no-28-tahun-1977,17 Januari 2017

RuchailisFahmi, "Pelaksanaan Sertifikasi Tanah Wakaf Di Kota Banjarmasin." Tesis. (Program Pasca Sarjana universitas Diponegoro, Semarang, 2008), h. 8 https://kepri.kemenag.go.id/files/kepri/file/file/Perpu/syvx1390190395.pdf , 17 Januari 2017 